\title{
Pengaruh Resiko Kredit, Likuiditas, Efisiensi Operasional dan Tingkat Ekonomi Makro Ekonomi Terhadap Kinerja Bank Pembangunan Daerah di Pulau Sumatera
}

\author{
Verawaty, Ade Kemala Jaya, Yolanda Widiati \\ verawaty_mahyudin@yahoo.com,jaya_ade@yahoo.com,yolanw25@gmail.com \\ Universitas Bina Darma
}

\begin{abstract}
The purpose of this study was to obtain the empirical evidence about the effect of credit risk, liquidity, operational efficiency and the macro-economic level to the the performance of regional development banks. This study population was eight Regional Development Banks in Sumatera Island during 2011-2014. Analysis technique used is multiple linear regression. The results showed simultaneously, all the independent variables affected the dependent variable. Partially, only credit risk and efficiency negatively affected the performance of the bank. Liquidity and macro-economic level did not have positive influence on the bank's performance.
\end{abstract}

Keywords: the performance of banks, credit risk, liquidity, operational efficiency and macro-economic level

\section{PENDAHULUAN}

Pelaksanaan program pembangunan Indonesia diadakan untuk meningkatkan kualitas hidup masyarakat, tujuan tersebut diwujudkan melalui peningkatan pendapatan dengan berbagai kegiatan yang produktif untuk menciptakan perekonomian yang stabil. Stabilitas perekonomian Indonesia membutuhkan ketersediaan dan peran serta lembaga keuangan. Pada saat ini terdapat dua jenis lembaga keuangan, yaitu lembaga keuangan bank dan lembaga keuangan bukan bank. Salah satu sarana yang mempunyai peranan strategis dalam kegiatan perekonomian adalah lembaga keuangan bank. Bank merupakan lembaga keuangan yang fungsi utamanya adalah menghimpun dana dari masyarakat, menyalurkan dana kepada masyarakat, dan juga memberikan pelayanan dalam bentuk jasa perbankan. Bank memiliki tiga fungsi utama, yaitu melakukan aktivitas dalam menghimpun dana kepada pihak ketiga, aktivitas penyaluran dana kepada pihak yang membutuhkan dana dan aktivitas bank dalam memberikan pelayanan jasa kepada masyarakat. Dari ketiga fungsi tersebut, bank dapat mengembangkan dalam berbagai macam produk bank, yaitu produk bank yang berkaitan dengan penghimpunan dana dan pelayanan jasa (Ismail, 2012).

Dalam prakteknya bank dibagi atas beberapa jenis. Jika ditinjau dari segi fungsinya bank dikelompokkan menjadi tiga jenis, yaitu Bank Sentral, Bank Umum, dan Bank Perkreditan Rakyat. Namun setelah keluar UU Pokok Perbankan No. 7 Tahun 1992 dan ditegaskan lagi dengan keluarnya UU RI No. 10 Tahun 1998, maka jenis perbankan terdiri dari Bank Umum dan Bank Perkreditan Rakyat.

Kinerja bank yang baik menjadi salah satu alasan bagi para investor untuk menanamkan dananya dalam bank tersebut karena dengan kinerja yang baik diharapkan dapat meningkatkan kekayaan pemegang sahamnya. Bagi perusahaan perbankan, kinerja keuangan merupakan bagian dari kinerja bank secara keseluruhan. Tingkat kinerja keuangan bank dapat dinilai dari beberapa indikator. Salah satu sumber utama indikatornya adalah laporan keuangan bank yang bersangkutan.

Ukuran untuk melihat kinerja keuangan perbankan adalah melalui profitabilitas, dimana tujuan utama operasional bank adalah mencapai tingkat profitabilitas yang maksimal. Profitabilitas merupakan kemampuan bank untuk menghasilkan laba secara efektif dan efisien. Semakin besar profitabilitas suatu bank, semakin besar pula tingkat keuntungan yang dicapai bank tersebut dan semakin baik pula posisi bank tersebut dari segi penggunaan aset. Beberapa faktor keuangan yang mempengaruhi kinerja bank di antaranya resiko kredit, likuiditas dan efisiensi operasional. Hal yang mempengaruhi kinerja bank tersebut merupakan rasio-rasio keuangan sekaligus sebagai alat ukur penilaian kinerja bank.

Penelitian ini merupakan pengembangan dari penelitian yang dilakukan Sudiyatno dan Fatmawati (2013), tetapi terdapat perbedaan dengan penelitian tersebut ataupun penelitian sebelumnya. Penelitian yang dilakukan Sudiyatno dan Fatmawati (2013) menyarankan untuk 
menambahkan variabel tingkat ekonomi makro, dimana kondisi kinerja bank tidak hanya dipengaruhi dari kinerja keuangan tapi dari tingkat ekonomi makro. Faktor tingkat ekonomi makro yang mempengaruhi kinerja bank adalah inflasi, produk domestik bruto dan suku bunga BI. Pada penelitian ini peneliti memilih suku bunga BI yang mempengaruhi kinerja bank dimana kenaikan suku bunga yang ditetapkan oleh Bank Indonesia mendorong terjadinya kenaikan tingkat suku bunga kredit

Pada penelitian ini Bank Pembangunan Daerah dipilih sebagai objek penelitian karena pentingnya peran sektor perbankan, maka perbankan yang kuat dan sehat sangat dibutuhkan bagi kelangsungan pembangunan ekonomi di Indonesia yang tentunya dimulai dari daerah-daerah hingga sampai ke pusat. Bank Pembangunan Daerah adalah bank milik pemerintah yang sangat strategis untuk mewujudkan pembangunan ekonomi di daerah. Bank Pembangunan Daerah yang kepemilikan sahamnya dimiliki pemerintah daerah dan penyumbang pendapatan asli daerah (PAD). Jika kinerja Bank Pembangunan Daerah meningkat dari profitabilitas maka menambah pendapatan asli daerah dimana Bank Pembangunan Daerah tersebut berlokasi, yaitu delapan Bank Pembangunan Daerah yang ada di Pulau Sumatera.

\section{TINJAUAN PUSTAKA \\ Teori-Teori yang Digunakan \\ Teori Keagenan}

Teori keagenan (agency theory) merupakan basis teori yang mendasari praktek bisnis perusahaan yang dipakai selama ini. Teori tersebut berakar dari sinergi teori ekonomi, teori keputusan, sosiologi dan teori organisasi. Teori keagenan atau agency theory dikemukakan oleh Michael C. Jensen dan William H. Meckling dalam Saryani (2014) menjelaskan adanya hubungan kontraktual antara dua atau lebih pihak, dimana salah satu pihak disebut prinsipal (principal) yang menyewa pihak lain disebut agen (agent) dalam melakukan beberapa jasa atas nama pemilik yang meliputi pendelegasian wewenang. Pihak prinsipal menentukan pendelegasian pertanggungjawaban kepada agen. Dalam hubungan prinsipal (masyarakat) dan agen (manajemen perbankan) pada perusahaan perbankan dipengaruhi dengan keberadaan regulator yaitu pemerintah melalui BI.

Keterkaitan teori agensi pada penelitian yaitu menjelaskan bahwa adanya konflik yang timbul dari agen, prinsipal, debitur, kreditur dan regulator. Masalah agensi pada bank menimbulkan agency problem. Agency problem adalah permasalahan yang timbul sebagai akibat adanya perbedaan atas pihak yang berkepentingan di bank, hal ini yakni berkaitan dengan fungsi bank sebagai lembaga intermediasi dan kinerja bank yang di bawah pengawasan Bank Indonesia.

\section{Penelitian-Penelitian Terdahulu dan Pengembangan Hipotesis Pengaruh Resiko Kredit terhadap Kinerja Bank}

Resiko kredit akan dihadapi oleh bank ketika nasabah (customer) gagal dalam membayar hutang atau kredit yang diterimanya pada saat jatuh tempo (Sudiyatno dan Fatmawati, 2012). Resiko kredit semakin besar bila bank tidak mampu meningkatkan atau memperbaiki kualitas kredit yang disalurkan, menunjukkan kinerja bank yang buruk.

Penelitian Mawardi (2005) dan Puspitasari (2009) menunjukkan hasil rasio Non Performing Loan (NPL) berpengaruh negatif dan berpengaruh signifikan terhadap Return on Assets (ROA). Namun penelitian pada Matindas, dkk (2012) menunjukkan hasil NPL tidak berpengaruh negatif terhadap ROA serta pada penelitian Sukarno dan Syaicu (2006) menunjukkan NPL berpengaruh positif. Hasil penelitian terdahulu masih menghasilkan temuan yang tidak konsisten, sehingga perlu dilakukan pengujian lebih lanjut untuk mengetahui konsistensi temuan jika diterapkan pada kondisi lingkungan yang berbeda. Oleh karena ketidakkonsistenan hasil, maka peneliti ingin menguji kembali hubungan efisiensi operasional terhadap kinerja bank ke dalam hipotesis sebagai berikut:

\section{H1: Resiko kredit berpengaruh negatif terhadap kinerja Bank Pembangunan Daerah di Pulau Sumatera}

\section{Pengaruh Likuiditas terhadap Kinerja Bank}

Likuiditas bank adalah kemampuan bank untuk memenuhi kemungkinan ditariknya deposito atau simpanan oleh deposan atau penitip dana ataupun memenuhi kebutuhan masyarakat berupa kredit (Kasmir, 2014). Bank dianggap semakin likuid dimana bank mampu memenuhi kredit tanpa 
adanya sesuatu penundaan (kredit yang cepat direalisasi). Hal ini mencerminkan kondisi kinerja bank yang efektif melayani nasabahnya.

Penelitian Sukarno dan Syaicu (2006), Puspitasari (2009), serta Miadalynl dan Dewi (2012) menunjukkan bahwa Loan Deposit to Ratio (LDR) berpengaruh positif dan signifikan terhadap ROA. Namun pada penelitian Yuliani (2007), LDR menunjukkan hasil tidak berpengaruh positif terhadap ROA. Hasil penelitian terdahulu masih menghasilkan temuan yang tidak konsisten, sehingga perlu dilakukan pengujian lebih lanjut untuk mengetahui konsistensi temuan jika diterapkan pada kondisi lingkungan yang berbeda. Oleh karena ketidakkonsistenan hasil, maka peneliti ingin menguji kembali hubungan likuiditas bank terhadap kinerja bank ke dalam hipotesis sebagai berikut:

H2: Likuiditas berpengaruh positif terhadap kinerja Bank Pembangunan Daerah di Pulau Sumatera

\section{Pengaruh Efisiensi Operasional terhadap Kinerja Bank}

Efisiensi operasional kemampuan bank dalam menjalankan faktor produksi. Kemampuan bank mengefisiensikan biaya operasionalnya akan dapat meningkatkan kemampuan bank dalam menghasilkan keuntungan. Semakin tinggi biaya operasional yang dikeluarkan oleh bank, maka akan menurunkan pendapatan operasional bank, sehingga kinerja bank membaik.

Penelitian Mawardi (2005), Sudiyatno dan Suroso (2010) dan Matindas, dkk (2012) menunjukkan hasil Biaya Operasional terhadap Pendpaatan Operasional (BOPO) berpengaruh negatif dan signifikan. Namun pada penelitian Nusantara (2009) menunjukkan hasil BOPO tidak berpengaruh terhadap ROA. Hasil penelitian terdahulu masih menghasilkan temuan yang tidak konsisten, sehingga perlu dilakukan pengujian lebih lanjut untuk mengetahui konsistensi temuan jika diterapkan pada kondisi lingkungan yang berbeda. Oleh karena ketidakkonsistenan hasil, maka peneliti ingin menguji kembali hubungan efisiensi operasional terhadap kinerja bank ke dalam hipotesis sebagai berikut:

H3: Efisiensi operasional berpengaruh negatif terhadap kinerja Bank Pembangunan Daerah di Pulau Sumatera

\section{Pengaruh Tingkat Ekonomi Makro terhadap Kinerja Bank}

Faktor tingkat ekonomi makro yang mempengaruhi profitabilitas bank adalah suku bunga. Kenaikan suku bunga yang ditetapkan oleh Bank Indonesia mendorong terjadinya kenaikan tingkat suku bunga kredit. Penetapan tingkat suku bunga ini disebut sebagai tingkat suku bunga dasar atau tingkat suku bunga acuan (Sinungan, dalam Puspitasari 2009). Kenaikan suku bunga yang ditetapkan oleh bank Indonesia mendorong terjadinya kenaikan tingkat suku bunga kredit. Kenaikan suku bunga kredit menyebabkan biaya bunga pinjaman ikut meningkat, sehingga pendapatan yang diterima bank dari bunga pinjaman kredit akan ikut meningkat. Jika pendapatan bunga bank naik maka akan meningkatkan laba atau keuntungan bank yang bersangkutan (dengan asumsi kenaikan suku bunga diikuti oleh kenaikan suku bunga kredit sehingga biaya bunga ikut naik dan pendapatan bunga yang diterima bank akan semakin besar).

Penelitian Kurniasih (2012) menunjukkan hasil penelitian suku bunga berpengaruh positif dan signifikan terhadap ROA. Namun pada penelitian Puspitasari (2009), suku bunga tidak berpengaruh terhadap ROA dan penelitian Gede, dkk (2013), suku bunga berpengaruh negatif terhadap ROA. Hasil penelitian terdahulu masih menghasilkan temuan yang tidak konsisten, sehingga perlu dilakukan pengujian lebih lanjut untuk mengetahui konsistensi temuan jika diterapkan pada kondisi lingkungan yang berbeda. Oleh karena ketidakkonsistenan hasil, maka peneliti ingin menguji kembali hubungan tingkat ekonomi terhadap kinerja bank ke dalam hipotesis sebagai berikut:

H4: Tingkat ekonomi makro berpengaruh positif terhadap kinerja Bank Pembangunan Daerah di Pulau Sumatera

\section{Pengaruh Resiko Kredit, Likuiditas, Efisiensi Operasional Dan Tingkat Ekonomi Makro Ekonomi terhadap Kinerja Bank \\ Menurut Gilbert dalam Sukarno dan Syaicu (2006) menyatakan ukuran kinerja perbankan yang paling tepat adalah dengan mengukur kemampuan perbankan dalam menghasilkan laba atau profit dari berbagai kegiatan yang dilakukannya, sebagaimana umumnya tujuan suatu perusahaan didirikan adalah untuk mencapai nilai (value) yang tinggi, dimana untuk mencapai value tersebut perusahaan harus dapat secara efisien dan efektif dalam mengelola berbagai macam kegiatannya.}


Salah satu ukuran untuk mengetahui seberapa jauh keefisienan dan keefektifan yang dicapai adalah dengan melihat profitabilitas perusahaan, semakin tinggi profitabilitas maka semakin efektif dan efisien juga pengelolaan kegiatan perusahaan.

Faktor keuangan yang mempengaruhi kinerja bank di antaranya resiko kredit, likuiditas dan efisiensi operasional. Hal yang mempengaruhi kinerja bank tersebut merupakan rasio-rasio keuangan sekaligus sebagai alat ukur penilaian kinerja bank. Kondisi kinerja bank tidak hanya dipengaruhi dari kinerja keuangan tapi dari tingkat ekonomi makro.

H5: Resiko kredit, likuiditas, efisiensi operasional dan tingkat ekonomi makro berpengaruh secara bersama terhadap kinerja bank.

\section{METODOLOGI PENELITIAN}

Variabel Operasional Variabel

\begin{tabular}{|c|c|c|c|}
\hline Variabel & Definisi & Indikator & $\begin{array}{l}\text { Skala } \\
\text { Ukur }\end{array}$ \\
\hline $\begin{array}{l}\text { Variabel } \\
\text { Dependen: } \\
\text { Kinerja Bank } \\
\text { Y: (ROA) }\end{array}$ & $\begin{array}{l}\text { Menurut Pandia (2012), rasio ini } \\
\text { menunjukkan tingkat efisiensi pengelolaan } \\
\text { aset yang dilakukan oleh bank yang } \\
\text { bersangkutan. ROA merupakan indikator } \\
\text { kemampuan perbankan untuk memperoleh } \\
\text { laba atas sejumlah aset yang dimiliki oleh } \\
\text { bank. }\end{array}$ & $\begin{array}{l}\text { - Laba } \\
\text { sebelum } \\
\text { pajak } \\
\text { - Total aset }\end{array}$ & Rasio \\
\hline $\begin{array}{l}\text { Variabel } \\
\text { Independen: } \\
\text { Resiko } \\
\text { Kredit } \\
\mathrm{X}_{1}:(\mathrm{NPL})\end{array}$ & $\begin{array}{l}\text { Menurut Surat Edaran Bank Indonesia No. } \\
\text { 13/24/DPNP, resiko kredit pada umumnya } \\
\text { terdapat pada seluruh aktivitas bank yang } \\
\text { kinerjanya bergantung pada kinerja pihak } \\
\text { lawan (counterparty), penerbit (issuer), } \\
\text { atau kinerja peminjam dana (borrower). }\end{array}$ & $\begin{array}{l}\text { - Kredit } \\
\text { bermasalah } \\
\text { - Total } \\
\text { kredit }\end{array}$ & Rasio \\
\hline $\begin{array}{l}\text { Likuiditas } \\
\text { Bank } \\
\mathrm{X}_{2:}(\mathrm{LDR})\end{array}$ & $\begin{array}{l}\text { Menurut Kasmir (2014), likuiditas bank } \\
\text { adalah kemampuan bank untuk memenuhi } \\
\text { kemungkinan ditariknya deposito atau } \\
\text { simpanan oleh deposan atau penitip dana } \\
\text { ataupun memenuhi kebutuhan masyarakat } \\
\text { berupa kredit. }\end{array}$ & $\begin{array}{l}\text { - Seluruh } \\
\text { kredit yang } \\
\text { diberikan } \\
\text { bank } \\
\text { - Dana pihak } \\
\text { ketiga }\end{array}$ & Rasio \\
\hline $\begin{array}{l}\text { Operasional } \\
\text { Bank } \\
\mathrm{X}_{3}:(\mathrm{BOPO})\end{array}$ & $\begin{array}{l}\text { Menurut Pandia (2012), BOPO merupakan } \\
\text { rasio yang sering digunakan untuk } \\
\text { mengukur kemampuan manajemen bank } \\
\text { dalam mengendalikan biaya operasional } \\
\text { terhadap pendapatan operasional. }\end{array}$ & $\begin{array}{l}\text { - Biaya } \\
\text { operasional } \\
\text { - Pendapatan } \\
\text { operasional }\end{array}$ & Rasio \\
\hline $\begin{array}{l}\text { Tingkat } \\
\text { Ekonomi } \\
\text { Makro } \\
\mathrm{X}_{4} \text { : (Suku } \\
\text { Bunga } \\
\text { BI) }\end{array}$ & $\begin{array}{l}\text { Suku bunga kebijakan yang mencerminkan } \\
\text { sikap atau stance kebijakan moneter yang } \\
\text { ditetapkan oleh Bank Indonesia dan } \\
\text { diumumkan kepada publik. }\end{array}$ & $\begin{array}{l}\text { - Suku } \\
\text { bunga BI }\end{array}$ & Nomina \\
\hline
\end{tabular}




\section{populasi dan Sampel}

Populasi dalam penelitian ini adalah seluruh Bank Pembangunan Daerah di Pulau Sumatera. Metode pemilihan sampel pada penelitian ini ditentukan dengan metode sampling jenuh dari jumlah populasi sebanyak delapan Bank Pembangunan Daerah di Pulau Sumatera, maka yang diambil sampel sebanyak delapan Bank Pembangunan Daerah (BPD) di Pulau Sumatera, yaitu BPD Aceh, BPD Sumatera Utara, BPD Sumatera Barat, BPD Riau dan Kepulauan Riau, BPD Jambi, BPD Sumatera Selatan dan Bangka-Belitung, BPD Bengkulu, dan BPD Lampung.

\section{Teknik Analisis}

Untuk menguji hipotesis, penelitian ini menggunakan analisis regresi linier berganda. Persamaan regresi yang digunakan dalam penelitian ini adalah:

$\mathrm{ROA}=\alpha+\beta_{1} \mathrm{NPL}+\beta_{2} \mathrm{LDR}+\beta_{3} \mathrm{BOPO}+\beta_{4} \mathrm{SBI}+\mathrm{e}$

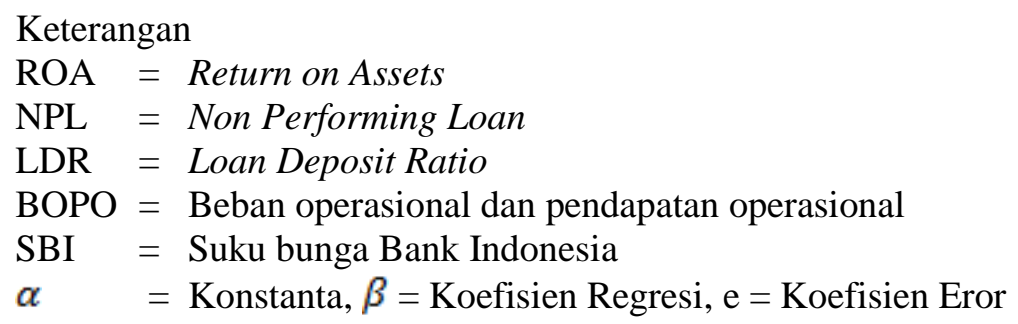

\section{HASIL DAN PEMBAHASAN}

Hasil dan Penelitian

Semua variabel penelitian telah lolos uji asumsi klasik. Hasil uji normalitas, yaitu nilai Kolmogorov-Smirnov (K-S) dan nilai Asymp. Sig. (2-tailed) dengan seluruh variabel di atas $\alpha=0,05$ yang berarti data yang diuji terdistribusi normal. Hasil uji multikolinearitas menyatakan nilai tolerance untuk seluruh variabel lebih besar dari $10 \%$ dan VIF lebih kecil dari 10 yang berarti bahwa data penelitian ini tidak terjadi multikolinearitas. Hasil uji heteroskedastisitas menyatakan nilai signifikansi untuk setiap variabel bebas terhadap nilai absolute residual lebih besar dari 0,05 yang berarti bahwa tidak terjadi gejala heteroskedastisitas dalam penelitian ini.

Uji Koefisien Determinasi (R2)

\begin{tabular}{|c|c|r|}
\hline Model & R Square & Adjusted R Square \\
\hline 1 & .444 & .362 \\
\hline
\end{tabular}

Tabel menunjukkan nilai adjusted $\mathrm{R}^{2}$ yaitu 0,362 , hal ini berarti $36,2 \%$ variabel kinerja bank yang diproksikan ROA dijelaskan oleh variabel resiko kredit (NPL), likuiditas (LDR), efisiensi operasional (BOPO) dan tingkat ekonomi makro (suku bunga BI), sedangkan sisanya 63,8\% merupakan pengaruh dari sebab-sebab atau faktor lain di luar model penelitian.

\section{Uji Signifikansi Simultan (Uji F)}

\begin{tabular}{|c|c|c|c|c|c|}
\hline Model & $\begin{array}{c}\text { Sum of } \\
\text { Squares }\end{array}$ & df & Mean Square & $\mathrm{F}$ & Sig. \\
\hline 1 Regression & 5,333 & 4 & 1,333 & 5,401 &, $003^{b}$ \\
\hline Residual & 6,665 & 27 & ,247 & & \\
\hline Total & 11,998 & 31 & & & \\
\hline
\end{tabular}

Berdasarkan hasil uji ANOVA atau $\mathrm{F}$ test di atas, didapat $\mathrm{F}$ hitung sebesar 5,401 lebih besar dari $\mathrm{F}$ tabel sebesar 2,728 dengan tingkat probabilitas 0,003 (signifikan) lebih kecil dari 0,05. Tabel yaitu hasil uji $\mathrm{F}$ (regresi simultan) juga menunjukkan bahwa nilai signifikan lebih besar dari tingkat signifikansi 0,05 , jadi dapat disimpulkan bahwa resiko kredit, likuiditas,efisiensi operasional dan tingkat ekonomi makro berpengaruh secara bersama terhadap kinerja bank. 
Coefficients $^{\mathrm{a}}$

\begin{tabular}{|c|c|c|c|c|c|}
\hline \multirow[b]{2}{*}{ Model } & \multicolumn{2}{|c|}{ Unstandardized Coefficients } & \multirow{2}{*}{\begin{tabular}{|c}
$\begin{array}{r}\text { Standardized } \\
\text { Coefficients }\end{array}$ \\
Beta \\
\end{tabular}} & \multirow[b]{2}{*}{$\mathrm{T}$} & \multirow[b]{2}{*}{ Sig. } \\
\hline & B & Std. Error & & & \\
\hline $1 \quad$ (Constant) & 4,764 & 1,536 & & 3,102 & ,004 \\
\hline Resiko Kredit &,- 119 &, 054 &,- 411 & $-2,226$ & ,035 \\
\hline Likuiditas &, 001 & ,007 & ,018 & ,122 & ,904 \\
\hline Efisiensi &,- 035 & ,019 &,- 337 & $-1,795$ & ,084 \\
\hline $\begin{array}{l}\text { Tingkat } \\
\text { Ekonomi Makro }\end{array}$ & ,157 & ,145 & 161 & 1,082 & 289 \\
\hline
\end{tabular}

Berdasarkan hasil uji statistik t pada tabel di atas, terlihat bahwa variabel resiko kredit (NPL) menunjukkan hubungan yang negatif signifikan terhadap variabel dependen, yaitu kinerja bank (ROA) dengan tingkat signifikan 5\%. Adapun efisiensi operasional (BOPO) menunjukkan hubungan yang negatif signifikan terhadap variabel dependen, yaitu kinerja bank (ROA) dengan tingkat signifikan $10 \%$. Hal ini dapat dilihat dari nilai probabilitas signifikan untuk resiko kredit 0,035 (sig. $<5 \%$ ), sedangkan nilai probabilitas signifikan untuk efisiensi operasional sebesar 0,085 (sig. $<10 \%)$.

\section{Pembahasan}

\section{Resiko Kredit Berpengaruh Negatif terhadap Kinerja Bank}

Berdasarkan hasil perhitungan dengan program SPSS diperoleh t-hitung sebesar 2,226 lebih dari t-tabel 1,703 dan tingkat signifikannya 0,035 kurang dari 0,05 dan 0,1. Hasil penelitian membuktikan bahwa resiko kredit berpengaruh negatif terhadap kinerja bank. Dengan demikian secara parsial hipotesis pertama diterima, artinya dalam penelitian ini semakin tinggi resiko kredit suatu bank mengurangi manajemen bank untuk memperoleh laba. Hasil analisis tersebut konsisten dengan hasil penelitian Mawardi (2005) dan Puspitasari (2009) menyatakan hasil resiko kredit memiliki pengaruh negatif dan signifikan terhadap kinerja bank. Hasil ini tidak konsisten dengan Matindas, dkk (2012) menunjukkan hasil resiko kredit tidak berpengaruh negatif terhadap kinerja bank.

Resiko kredit didefinisikan sebagai resiko kerugian sehubungan dengan pihak meminjam yang tidak dapat atau tidak mau memenuhi kewajiban untuk membayar kembali dana yang dipinjamkannya secara penuh pada saat jatuh tempo atau sesudahnya (Pandia, 2012). Kredit bermasalah adalah kredit dengan kualitas kurang lancar, diragukan dan macet. Semakin tinggi rasio NPL, maka akan semakin buruk kualitas kredit bank yang menyebabkan jumlah kredit bermasalah semakin besar. Jika Rasio NPL besar maka bank harus menanggung kerugian dalam kegiatan operasionalnya sehingga berpengaruh kredit yang diberikan kepada pihak ketiga tidak termasuk kredit kepada bank lain (Kasmir, 2014)

Hasil penelitian ini menunjukkan resiko kredit berpengaruh negatif terhadap kinerja bank. Resiko kredit semakin tinggi artinya bank banyak mengalami kredit bermasalah. Jika pihak bank tidak memberikan solusi terhadap kredit bermasalah menyebabkan besarnya piutang tak tertagih dan tertahannya dana bank di pihak debitur yang merugikan kegiatan operasional bank.

Resiko kredit bank yang tinggi menimbulkan masalah hubungan agen dengan regulator. Bank beroperasi di bawah regulasi yang secara substansial berbeda dengan perusahaan nonbank dan ini biasa mempengaruhi sifat dan efektivitas mekanisme kontrol. Regulasi mengarahkan manajemen bank untuk mengelola bank secara hati-hati. Prinsip kehati-hatian mengindikasikan adanya pencegahan terhadap moral hazard. Keberadaan regulator ikut mempengaruhi keputusan-keputusan manajemen bank (Taswan, 2010).

\section{Likuiditas Berpengaruh Positif terhadap Kinerja Bank}

Berdasarkan hasil perhitungan dengan program SPSS diperoleh t-hitung sebesar 0,122 kurang dari t-tabel 1,703 dan tingkat signifikannya 0,904 lebih besar dari 0,05 dan 0,1. Hasil 
penelitian ini membuktikan bahwa likuiditas tidak berpengaruh positif terhadap kinerja bank. Dengan demikian secara parsial hipotesis kedua ditolak. Hasil analisis tersebut tidak konsisten dengan hasil penelitian Sukarno dan Syaicu (2006), Puspitasari (2009), serta Miadalynl dan Dewi (2012). Hasil analisis konsisten dengan penelitian yang dilakukan Yuliani (2007) dan Sudiyatno dan Fatmawati (2013) menunjukkan hasil likuiditas tidak berpengaruh terhadap kinerja bank.

Rasio likuiditas diwakilkan rasio LDR yang menyatakan seberapa jauh bank telah menggunakan uang para penyimpan (depositor) untuk memberikan pinjaman kepada nasabahnya. Dengan kata lain jumlah uang yang dipergunakan untuk memberi pinjaman adalah uang yang berasal dari titipan para penyimpan (Pandia, 2012). Semakin tinggi Loan to Deposit Ratio (LDR) menunjukkan semakin riskan kondisi likuiditas bank, sebaliknya semakin rendah LDR menunjukkan kurangnya efektivitas bank dalam menyalurkan kredit sehingga hilangnya kesempatan bank untuk memperoleh laba. (Dendawijya dalam Syarir, 2012).

Berdasarkan tabel uji T, terbukti bahwa likuiditas tidak berpengaruh positif terhadap kinerja bank. Alasannya bank sebagai lembaga yang berfungsi intermediasi belum efektif dengan penyaluran kredit dan penggunaan dana serta mencerminkan kemampuan bank dalam kewajiban atas dana pihak ketiga belum berjalan optimal padahal semakin tinggi likuiditas bank, maka dana pihak ketiga yang disalurkan bentuk kredit semakin besar. Penggunaan dana tidak tepat menggunakan menimbulkan masalah keagenan pada saat manajer memutuskan untuk melakukan investasi yang berisiko tinggi. Keputusan semacam itu bila berjalan baik akan sangat menguntungkan bagi bank, tetapi jika gagal akan sangat merugikan bagi deposan.

\section{Efisiensi Operasional Berpengaruh Negatif terhadap Kinerja Bank}

Berdasarkan hasil perhitungan dengan program SPSS diperoleh t-hitung sebesar 1,795 lebih dari t-tabel 1,314 dan tingkat signifikannya 0,085 kurang dari 0,1 . Hasil penelitian ini membuktikan bahwa efisiensi operasional berpengaruh negatif terhadap kinerja bank. Dengan demikian hipotesis ketiga secara parsial diterima. Hasil analisis tersebut konsisten dengan hasil penelitian Mawardi (2005), Sudiyatno dan (2010) dan Matindas, dkk (2012) efisiensi operasional berpengaruh negatif terhadap kinerja bank. Namun pada penelitian Nusantara (2009) menunjukkan hasil efisiensi operasional tidak berpengaruh negatif terhadap kinerja bank.

Efisiensi operasional kemampuan bank dalam menjalankan faktor produksi. Pengendalian efisiensi operasional harus diperhatikan secara sungguh-sungguh oleh bank agar dapat memperoleh pendapatan yang maksimal sehingga juga akan meningkatkan kinerja bank dalam hal ini adalah untuk memperoleh laba. Semakin besar efisiensi operasional maka semakin tidak efisien suatu bank, efisiensi bank dikatakan membaik ditunjukkan oleh penurunan nilai efisiensi operasional (BOPO). Rasio yang sering digunakan untuk mengukur kemampuan manajemen bank dalam mengendalikan biaya operasional terhadap pendapatan operasional (Pandia, 2012). Efisiensi operasional (BOPO) dirumuskan sebagai perbandingan rasio biaya operasional dalam 12 bulan terakhir terhadap pendapatan operasional dalam periode yang sama. BOPO dapat dihitung melalui daftar laba rugi perbankan (Hasibuan, 2011).

Hasil penelitian ini menunjukkan efisiensi operasional bank berpengaruh negatif terhadap kinerja bank. Efisiensi berpengaruh negatif terhadap kinerja bank artinya semakin besar nilai efisiensi operasional maka menurunkan profitabilitas bank. Jika kegiatan operasional bank efisien maka menurunkan nilai efisiensi operasional serta meningkatkan pendapatan bank yang dihasilkan bank akan naik.

Efisiensi operasional melibatkan kebijakan manajemen bank. Manajemen bank yang buruk menimbulkan konflik hubungan konflik keagenan dengan principal (pemegang saham). Manajemen bank memiliki kecenderungan untuk memperoleh keuntungan sebesar-besarnya dengan biaya yang ditanggung oleh principal (pemegang saham). Perilaku ini sering disebut sebagai keterbatasan rasional atau bounded rationality dan tidak suka menanggung resiko atau risk adverse (Taswan, 2010).

\section{Tingkat Ekonomi Makro Berpengaruh Positif terhadap Kinerja Bank}

Berdasarkan hasil perhitungan dengan program SPSS diperoleh t-hitung sebesar 1,082 kurang dari t-tabel 1,703 dan tingkat signifikannya 0,289 lebih dari 0,05 dan 0,1. Dengan demikian secara parsial menunjukkan bahwa hipotesis keempat ditolak. Hasil analisis konsisten dengan penelitian 
yang dilakukan Nusantara (2009) menunjukkan hasil tingkat ekonomi makro (suku bunga BI) tidak berpengaruh terhadap kinerja bank. Hasil ini tidak konsisten dengan penelitian Kurniasih (2012) menunjukkan tingkat ekonomi makro (suku bunga BI) berpengaruh positif dan signifikan terhadap kinerja bank.

Faktor tingkat ekonomi makro yang mempengaruhi kinerja bank adalah suku bunga BI. Suku bunga BI adalah suku bunga kebijakan yang mencerminkan sikap atau stance kebijakan moneter yang ditetapkan oleh Bank Indonesia dan diumumkan kepada publik. Menurut Puspitasari (2009), kenaikan suku bunga yang ditetapkan oleh Bank Indonesia mendorong terjadinya kenaikan tingkat suku bunga kredit. Kenaikan suku bunga kredit menyebabkan biaya bunga pinjaman ikut meningkat, sehingga pendapatan yang diterima bank dari bunga pinjaman kredit akan ikut meningkat.

Hasil penelitian ini tingkat ekonomi makro tidak berpengaruh positif terhadap kinerja bank. Alasannya kenaikan suku bunga Bank Indonesia akan meningkatkan suku bunga kredit pinjaman dan meningkatkan juga biaya bunga kreditnya, tetapi selisih peningkatan bunga kreditnya dengan pendapatan bunga kreditnya kecil, dan fluktuasi per tahunnya juga kecil atau rendah. Hal inilah yang menyebabkan pada penelitian ini suku bunga BI tidak berpengaruh positif signifikan terhadap kinerja bank.

\section{Pengaruh Resiko Kredit, Likuiditas, Efisiensi Operasional dan Tingkat Ekonomi Makro Ekonomi terhadap Kinerja Bank}

Berdasarkan hasil perhitungan dengan program SPSS diperoleh F-hitung sebesar 5,401 lebih besar dari F-tabel 2,728 dan tingkat signifikannya 0,003 kurang dari 0,05. Hasil penelitian menunjukkan variabel bebas mempengaruhi variabel dependen. Artinya, setiap perubahan yang terjadi pada variabel bebas yaitu resiko kredit, likuiditas, efisiensi operasional dan tingkat ekonomi makro secara simultan atau bersama-sama akan berpengaruh pada kinerja bank.

Menurut Gilbert dalam Sukarno dan Syaicu (2006) menyatakan ukuran kinerja perbankan yang paling tepat adalah dengan mengukur kemampuan perbankan dalam menghasilkan laba atau profit dari berbagai kegiatan yang dilakukannya, sebagaimana umumnya tujuan suatu perusahaan didirikan adalah untuk mencapai nilai (value) yang tinggi, dimana untuk mencapai value tersebut perusahaan harus dapat secara efisien dan efektif dalam mengelola berbagai macam kegiatannya.

Menurut Sudiyatno dan Suroso (2010), kinerja keuangan adalah penentuan ukuran-ukuran tertentu yang dapat mengukur keberhasilan suatu perusahaan dalam menghasilkan laba, sedangkan kinerja keuangan bank merupakan gambaran kondisi keuangan bank pada periode tertentu baik menyangkut aspek penghimpunan dana maupun penyaluran dana. Kinerja bank juga dapat menunjukkan kekuatan dan kelemahan bank. Dengan mengetahui kekuatan bank, maka dapat dimanfaatkan untuk pengembangan usaha bank, sedangkan kelemahannya dapat dijadikan dasar untuk perbaikan di masa mendatang. Kinerja pada bank pada penelitian dipengaruhi resiko kredit, likuiditas efisiensi operasional dan tingkat ekonomi makro.

Keempat faktor tersebut menimbulkan masalah keagenan jika pihak bank menjalankan operasinya tidak efektif dan efisien. Masalah keagenan menimbulkan agency problem, sedangkan Agency problem adalah permasalahan yang timbul sebagai akibat adanya perbedaan atas pihak yang berkepentingan di perusahaan, hal ini berkaitan dengan fungsi bank sebagai lembaga intermediasi dan kinerja bank yang di bawah pengawasan Bank Indonesia. Konflik keagenan pada bank tidak dapat dihilangkan tapi pihak bank hanya bisa menguranginya.

\section{PENUTUP \\ Simpulan}

Berdasarkan pembahasan mengenai pengaruh resiko kredit, likuiditas, efisiensi operasional dan tingkat ekonomi makro ekonomi terhadap kinerja Bank Pembangunan Daerah di Pulau Sumatera, penulis menyimpulkan secara hasil pengujian simultan menunjukkan bahwa resiko kredit, likuiditas, efisiensi operasional dan tingkat ekonomi makro berpengaruh secara bersama terhadap kinerja bank dan hasil pengujian hipotesis. Hasil pengujian secara parsial menunjukkan resiko kredit dan efisiensi operasional berpengaruh negatif terhadap kinerja bank. Adapun likuiditas dan tingkat ekonomi makro tidak berpengaruh positif terhadap kinerja bank.

Dalam pemberian kredit seharusnya pihak bank menyeleksi calon debitur layak diberi pinjaman dan harus memiliki agunan sesuai syarat pemberian kredit sehingga mengurangi kredit 
bermasalah. Untuk efisiensi operasional pihak bank harus seefisien mungkin dalam kegiatan operasional caranya menyeleksi biaya-biaya yang dikeluarkan, dimana semakin besarnya nilai operasional bank mempengaruhi pendapatan bank dan menurunkan kinerja bank.

\section{Saran}

Bagi peneliti selanjutnya agar dapat memperbesar jumlah sampel, objek penelitian, dan menambahkan variabel lain yang mendukung likuiditas dan tingkat ekonomi makro karena hasil penelitian menunjukkan kedua variabel tidak berpengaruh terhadap kinerja bank. Dapat dilihat dari nilai adjusted $\mathrm{R}^{2}$ hanya sebesar $36,2 \%$ yang berarti ada $63,8 \%$ merupakan pengaruh dari variabelvariabel lainnya untuk menjelaskan kinerja bank, seperti giro wajib minum (GWI). Peneliti selanjutnya disarankan agar memperluas periode pengamatan agar lebih akurat dalam membandingkan hasil penelitian dari tahun ke tahun.

\section{DAFTAR PUSTAKA}

Gede, Dewa Nyoman, I Wayan, Sudirman I Wayan \& Sudjana, Budhiasa Gede. 2013. Dampak Kebijakan Moneter terhadap ROA Industri Perbankan Regional Studi Kasus pada PT Bank Sinar Harapan Bali. Jurnal Universitas Udayana. Bali.

Hasibuan, Malayu S. P. 2011. Dasar-Dasar Perbankan. Bumi Aksara. Jakarta.

Ismail. 2012. Akuntansi Bank. Edisi Ketiga. Kencana. Jakarta.

Kasmir. 2014. Manajemen Perbankan. Edisi Kedua belas. Raja Grafindo Persada. Jakarta.

Kurniasih, Erni. 2012. Pengaruh Capital Adequacy Ratio (CAR), Non Performing Financing (NPF), Financing to Deposit Ratio (FDR), Biaya Operasional terhadap Pendapatan Operasional (BOPO), Suku Bunga dan Inflasi terhadap Profitabilitas (Perbandingan Bank Umum Syariah dan Bank Umum Konvensional Periode 2007-2011. Skripsi. Yogyakarta, Universitas Islam Negeri Sunan Kalijaga.

Matindas, Anggria Maya, Pangemanan, Sifrid S \& Saerang, David P.E. 2012. Pengaruh Capital Adequacy Ratio (CAR), BOPO dan Non Performing Loan (NPL) terhadap Kinerja Keuangan Perbankan di Indonesia. Jurnal Ekonomi dan Bisnis Magister Akuntansi Universitas Sam Ratulangi. Manado

Mawardi, Wisnu. 2005. Analisis Faktor-faktor yang Mempengaruhi Kinerja Keuangan Bank Umum di Indonesia (Studi Kasus pada Bank umum dengan Total Assets Kurang dari 1 Trilliun). Jurnal Bisnis Strategi, Vol.14, No. 1.

Miadalynl, Putu Desi \& Dewi, Sayu Sutrisna. 2012. Pengaruh LDR, LAR, CAR, dan Kualitas Aktiva Produktif terhadap Profitabilitas pada BPD Bali. Jurnal Universitas Udayana. Bali.

Nusantara, Adnan Buyung. 2009. Analisis Pengaruh NPL, CAR, LDR, dan BOPO terhadap Profitabilitas Bank (Perbandingan Bank Umum Go Publik dan Bank Umum Non Go Publik di Indonesia Periode Tahun 2005-2007). Tesis Tidak Dipublikasikan. Universitas Diponegoro.

Pandia, Frianto.2012. Manajemen Dana dan Kesehatan Bank. Rineka Cipta. Jakarta

Puspitasari, Diana. 2009. Analisis Pengaruh CAR, NPL, PDN, NIM, BOPO, LDR, dan Suku Bunga SBI terhadap ROA (Studi pada Bank Devisa di Indonesia Periode 2003-2007). Thesis Tidak Dipublikasikan. Universitas Diponegoro.

Saryani, Dewi. 2014. Analisis Capital Adequacy Ratio, Non Performing Loan, Net Interest Margin, Biaya Operasional, Loan to Deposit Ratio, Ukuran Perusahaan terhadap Profitabilitas Bank Umum di Indonesia yang Terdaftar pada Bursa Efek Indonesia. Jurnal Universitas Pandanaran. Semarang.

Sudiyatno, Bambang \& Fatmawati, Asih. 2013. Pengaruh Risiko Kredit dan Efisiensi Operasional terhadap Kinerja Bank (Studi Empirik pada Bank yang Terdaftar di Bursa Efek Indonesia). Jurnal Organisasi dan Manajemen. Vol.9 No.1. STIE Stikubank.

Sudiyatno, Bambang \& Suroso, Jati. 2010. Analisis Pengaruh Dana Pihak Ketiga, BOPO, CAR dan LDR terhadap Kinerja Keuangan pada Sektor Perbankan yang Go Public di Bursa Efek Indonesia (BEI) Periode 2005-2008. Jurnal Dinamika Keuangan dan Perbankan.Vo.12 No.2. STIE Stikubank. 
Sukarno, Kartika Wahyu \& Syaicu, Muhamad. 2006. Analisis faktor-faktor yang mempengaruhi kinerja Bank umum di Indonesia. Jurnal Organisasi dan Manajemen, Vol 3 No.2.

Syarir, Asdini Andi. 2012. Analisis Pengaruh LDR, NPL dan CAR terhadap Risiko Likuiditas pada Bank Pembangunan Syarir Daerah (BPD) SE-Indonesia Tahun 2007-2011. Skripsi. Universitas Hasanudin. Makassar.

Taswan. 2010. Manajemen Perbankan Konsep, Teknik dan Aplikasi. UPP STIM YKPN. Yogyakarta. Undang-Undang Republik Indonesia Nomor 10 Tahun 1998. Perbankan. Jakarta.

Yuliani. 2007. Hubungan Efisiensi Operasional dengan Kinerja Profitabilitas pada Sektor Perbankan yang Go Public di Bursa Efek Infobank. Jurnal Manajemen dan Bisnis Sriwijaya Vol. 5, No 10. Palembang. 